\title{
Geomorphological heritage, conservation and promotion in high-alpine protected areas
}

\author{
Jean-Baptiste Bosson \& Emmanuel Reynard
}

Keywords: geoheritage management, geotourism, landscape, geomorphology, natural protected area

\section{Abstract}

In recent decades, recognition of both cultural and natural heritage has grown in the Alps. This tendency illustrates a collective identity building (local, national, alpine), but it also highlights, in the current context of global change, a renewed reflection of man's relationship with the environment. Thus, a fundamental and scientific intrinsic value (as a part of wilderness) tends to be recognized in the natural heritage as a whole. However, geoheritage (and geodiversity) is still often perceived as a secondary natural component, compared with bioheritage (and biodiversity). In this context, we study the geomorphological heritage (landforms and the processes that shape them) of Les Contamines-Montjoie Natural Reserve. Indeed, despite the high geomorphological richness (especially glacial) of the reserve, which covers more than 4000 ha of the Mont-Blanc Massif, local recognition of this heritage is still limited. In order to recognize and protect it, and starting with a scientific study, this research identifies the main local richness and assesses the geotourist and educational potentials. Finally, several tools to educate and promote geoheritage (educational paths and website) are proposed.
Profile

Protected Area

Les Contamines-Montjoie Natural

Reserve

Mountain range

Mont-Blanc massif, Alps

Country

France

\section{Introduction}

Since the Second World War, Alpine tourism has developed mainly as mass-tourism organized around winter sports. This industrial model now faces some important challenges, both from climate change and from competition with other tourist destinations (see e.g. Bourdeau 2009; Macchiavelli 2009). Tourist diversification and the development of sustainable practices during the summer season could be a good alternative and / or complement to the existing model of tourism. That is the reason for the recent development of new forms of qualitative tourism. These include geotourism, developed since the 1970s, a form of tourism exploiting natural sites for their earth science interest (Hose1996; Dowling \& Newsome 2006; Pralong 2006a and 2006b). It can be considered a form of specialized tourism, situated at the interface between natural area tourism (focused on wilderness), ecotourism (wilderness, education and sustainability), cultural tourism (heritages) and adventure tourism (thrill, exploration; see Dowling \& Newsome 2006). Geotourism is focused on education about the value of geosites - that is geological objects with a particular heritage value - for understanding earth history and about the links between geoheritage (geosites) and other types of heritage (biological and cultural heritage).

Geotourism seems to open up new interesting horizons in the Alps (Cayla 2009) for three main reasons. First, Alpine geoheritage (geological structures, lithologies, landforms, soils) is really rich and diverse, resulting from a complex geological and climatic history. The Alps have a high geodiversity that includes diversity of geological structures, lithologies, landforms and soils (see Gray 2004). Secondly, several scientific theories in earth sciences were developed in the Alps (e.g. tectonics, glaciology, etc.) and hold out great potential for developing educational activities in the earth science domain. Finally, geotourism practices are as old as Alpine tourism, although that has not been recognized until now (Reynard et al. 2011). Given the importance of tourism in the Alps, over 5 million people could be attracted by geotourism (Cayla 2009).

Natural protected areas (NPAs) are territories dedicated to the protection of natural assets and to environmental education. In the Alps, more than 1000 large protected areas cover about $25 \%$ of the Alpine Space as defined by the Alpine Convention (www.alparc.org, accessed 13/01/12). Hence there is significant potential for developing geotourism and educational programmes in the field of geosciences in Alpine PAs. Nevertheless, it has been observed (Sharples 2002; Carcavilla et al. 2009) in several countries that conservation policies have until now focused on protecting the biological part of nature rather than nature as a whole. That is the reason why biodiversity - and its protection - has a much wider audience than geodiversity concepts. Most scientists in earth sciences consider geodiversity as often underestimated in conservation strategies and want it recognized as a fundamental part of natural diversity rather than a simple complement to biodiversity (Serrano \& Ruiz-Flaño 2007). Therefore, there is a need for a better dissemination of the importance of geoheritage and geodiversity in larger circles, both in the wider public and among the managers of NPAs, as has been demonstrated by two 


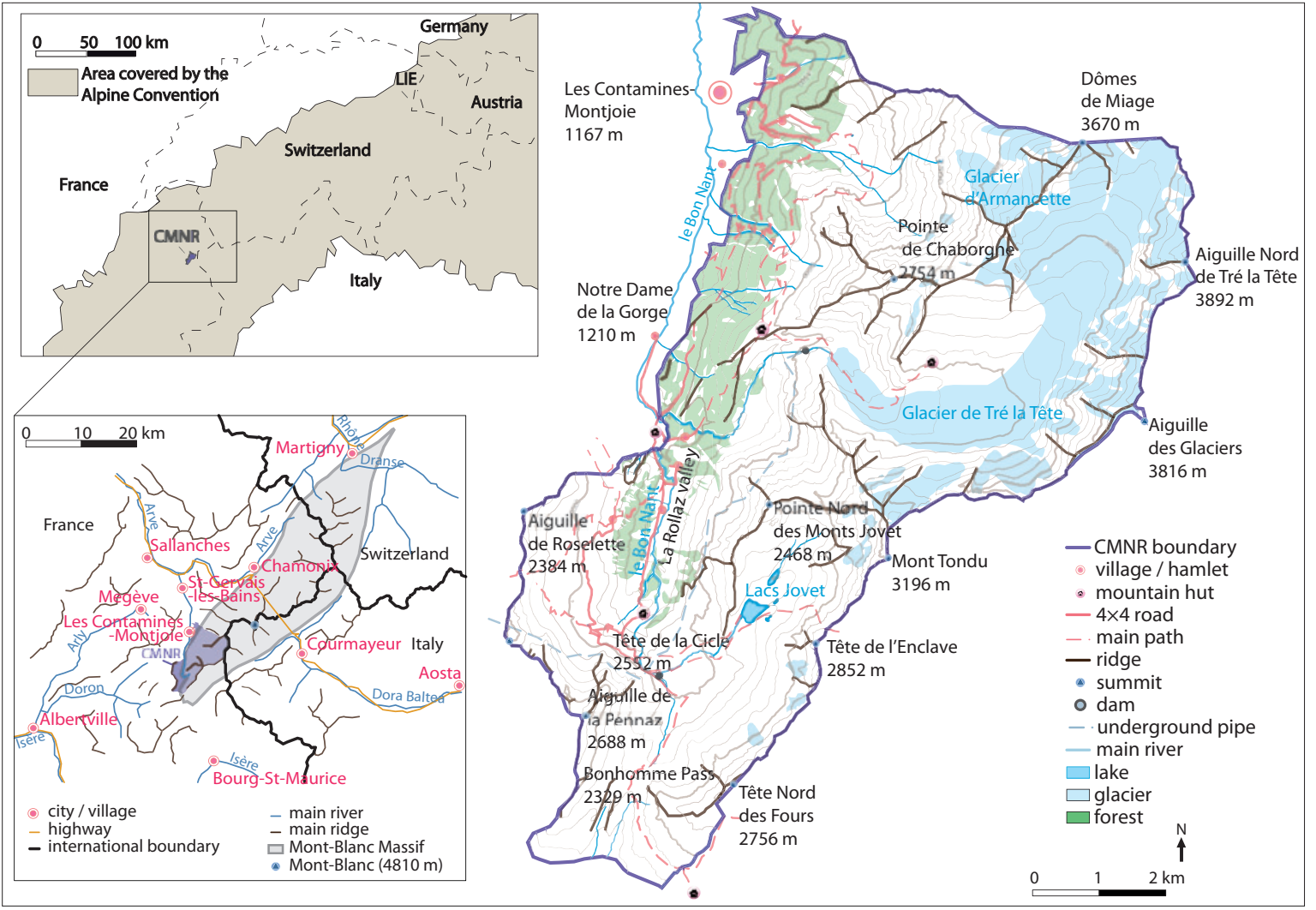

Figure 1 - Regional situation and map of the CMNR (Bosson 2010; modified).

recent surveys carried out in several new projects of NPAs in Switzerland (Fontana \& Reynard 2012; Kozlik in prep.). These surveys have shown the relatively poor knowledge of park promoters about the quality of geoheritage in the areas covered by their projects.

This article concerns the Contamines-Montjoie Natural Reserve (CMNR; Massif du Mont-Blanc, France, $\left.45^{\circ} 46^{\prime} 11^{\prime \prime} \mathrm{N}, 6^{\circ} 44^{\prime} 38^{\prime \prime} \mathrm{E}\right)$. Although the area has been protected since 1979 , management activities have so far mainly aimed at protecting specific biotopes, at the conservation of biodiversity and at sustainable management of natural resources (pastures, forests, landscapes, etc.). The main issue for the park managers is still to reconcile conservation with tourist development through information, regulation and planning (Asters 2004). Aware of the low recognition of geoheritage in this strategy, the objective of the research described here (Bosson 2010) was to develop a better knowledge of geoheritage that could, then, help to protect it.

Focusing on the geomorphological heritage (landforms and the processes that shape them $=\mathrm{a}$ part of the geoheritage) of CMNR, the project aimed at (1) carrying out a geomorphological survey in order to point out the intrinsic richness of this heritage; (2) proposing a selection of key sites for developing geotourist and educational activities; (3) proposing a strategy for developing geotourism. In order to produce a useful approach, we contacted park managers before, during and after the research with relative success (see discussion and conclusion below).

\section{Research area: Contamines-Montioie Natu- ral Reserve}

CMNR is situated at the southern rim of the MontBlanc massif (Figure 1). It is the only large institutional protected area in the whole massif, covering a surface of 5500 ha and an enormous altitudinal range (from 1100 to $3892 \mathrm{~m}$; more than $70 \%$ of the area is located above $2000 \mathrm{~m}$ ). With these particular characteristics, it is the highest and (vertically) most extended among the 266 French natural reserves (www.reservesnaturelles.org, accessed 14/01/12). The high geodiversity of CMNR is mainly due to a complex geological structure (autochthonous and allochthonous crystalline basement and sedimentary cover, Figure 2 and Figure 3). Moreover, the great altitudinal range allows the coexistence of heterogeneous geomorphological landforms and processes and explains the freshness of glacial heritage. De Saussure was studying local geology as early as 1779. Tré-la-Tête glacier, one of the largest French glaciers, currently occupies 830 ha of the reserve. However, recognition of this rich and diversified heritage is still limited.

Linked with the local geodiversity (high altitudinal range, microclimates, heterogeneous soils), biodiversity is particularly rich (679 flora species, with 59 strictly protected, and 236 fauna species; Asters 2004). Besides, because of the Bonhomme pass $(2329 \mathrm{~m}$, Figure 3) that connects the Arve valley (access to Lake Geneva basin and Valais) to the Tarentaise valley (access to Savoie and Aosta valley), human occupation 
goes back a long way. Currently, Les ContaminesMontjoie has 1200 inhabitants, 14000 tourist beds and $120 \mathrm{~km}$ of ski tracks. The development of mass tourism has led to the creation of CMNR, in order to conserve a natural area in the municipal territory. Although the infrastructure is limited, around 100000 people visit the reserve every year (hiking, trekking, mountaineering, etc.; Asters 2004). Thus, with a rich geoheritage and a high attendance rate, geotourism has promising development potential.

\section{Definitions and methods}

Let us clarify some terms that are used in this article. We consider geotourism as the set of all practices, interpretive facilities and services developed to promote the value of the geoheritage and its conservation for educative purposes (Hose 2008). The term geoheritage covers geological sites and materials (e.g. collections in museums) that present a heritage interest for society and should be conserved for future generations. In the same sense, the geomorphological heritage essentially concerns landforms and processes active at the earth surface. We call all sites of geological interest geosites; the term refers, therefore, to different types of interest (mineralogical, paleontological, geomorphological, etc.). In this paper, we focus on sites of geomorphological interest - that is landforms important for understanding the evolution of the earth surface reliefs. For this type of sites, we generally use the term geomorphosites (Panizza 2001). Each geosite is characterized by a certain value. We consider two types of value (Reynard 2005; Reynard et al. 2009): a central, scientific value - that is the importance of the site for the reconstruction of earth and climate history -, and several additional values (aesthetic, ecological, economic and cultural). Together, the scientific and additional values constitute what we consider the intrinsic quality of the geomorphosites. In addition, we can take into account a certain number of usage values - that is all the potentials that the site presents in terms of education, geotourism and conservation.

Throughout this research, we focused, first, on the recognition of the intrinsic value of the geomorphosites present in the reserve, especially the scientific importance of landforms and, secondly, on the potential of the reserve for the development of geotourist activities and facilities. In order to reach the first objective, we carried out a comprehensive geomorphological study of the reserve surface and produced three maps of the reserve area. All of them are completed by an explanatory folder and additional maps and figures. The first one is a geomorphological map that presents all the landforms recognized in the field and classified according to the various processes active in the area. The legend used was developed at the University of Lausanne (Schoeneich 1993; Schoeneich et al. 1998) and each process is represented by one colour; the erosional landforms are represented in the colour of the

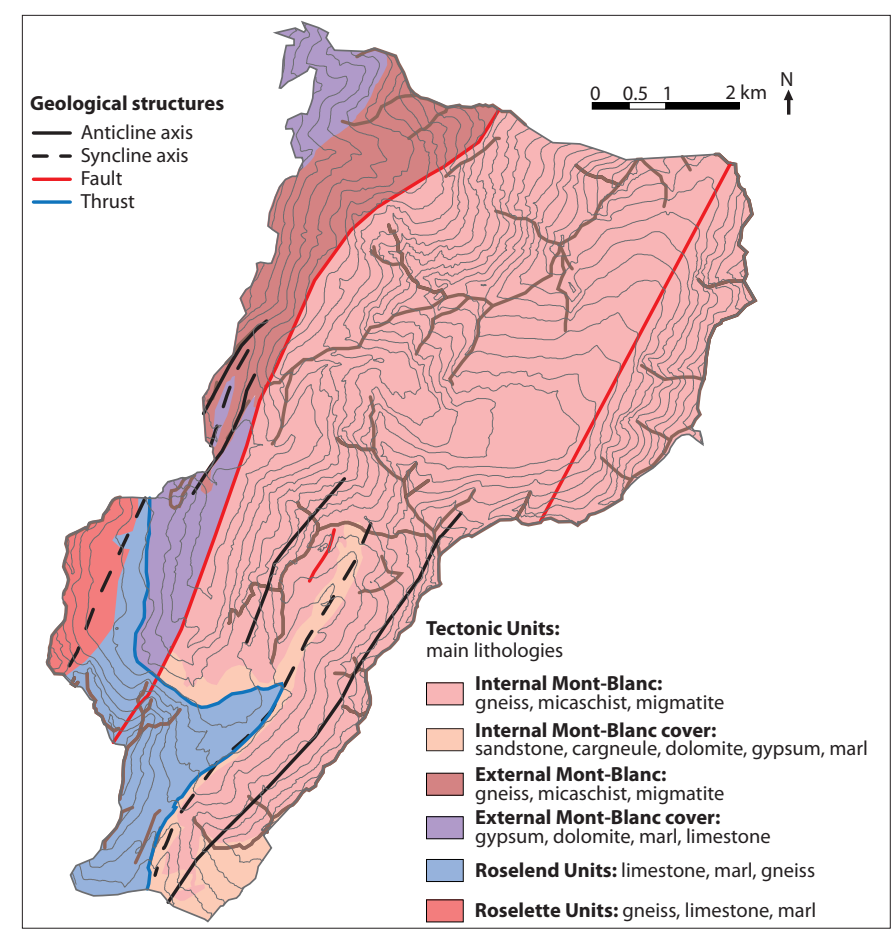

Figure 2 - Simplified geological map of CMNR (Bosson 2010; modified).

process on a white background, whereas depositional landforms are represented on a coloured background. The second map focuses on the glacial history of the reserve; it represents the various glacial stages following a specific method that allows the size of glaciers to be reconstructed for different climate situations and relative position changes of the equilibrium lines of glaciers (Maisch 1981). Thus, successive steps of landscape history can be pointed out. The third map is a geodynamic map (see e.g. Ballandras 2003); it allows us to visualize the most dynamic parts of the reserve in terms of geomorphological processes. This schematic map is based on the concept of sedimentary cascade (Schrott et al. 2003). Through field investigation, we have identified accumulation and transfer sectors and for each of them we have attributed the activity and the dominant morphological process. With the help of these three complementary maps, we may understand the past, present and potential future evolution of local relief. Moreover, representativeness, rareness, integrity and paleogeographical values of the geomorphological heritage can be identified with these analyses.

The selection of geomorphosites worth promoting through geotourist products is inspired by the methods developed by Pralong (2005), De Wever et al. (2006) and Reynard et al. (2007), adapted for the selection of sites that present good potential for geotourist purposes. What is original of the method proposed here is the scale of analysis and assessment that is geomorphological landscapes $(\mathrm{GL}=$ macro geosites, Reynard 2005). Indeed, ten landscapes of CMNR, characterized by their consistency and / or their homogeneous geomorphology (glacier catchment, valley, etc.) were identified by the geomorphological analysis. Then, both the scientific and the geotourist interests 


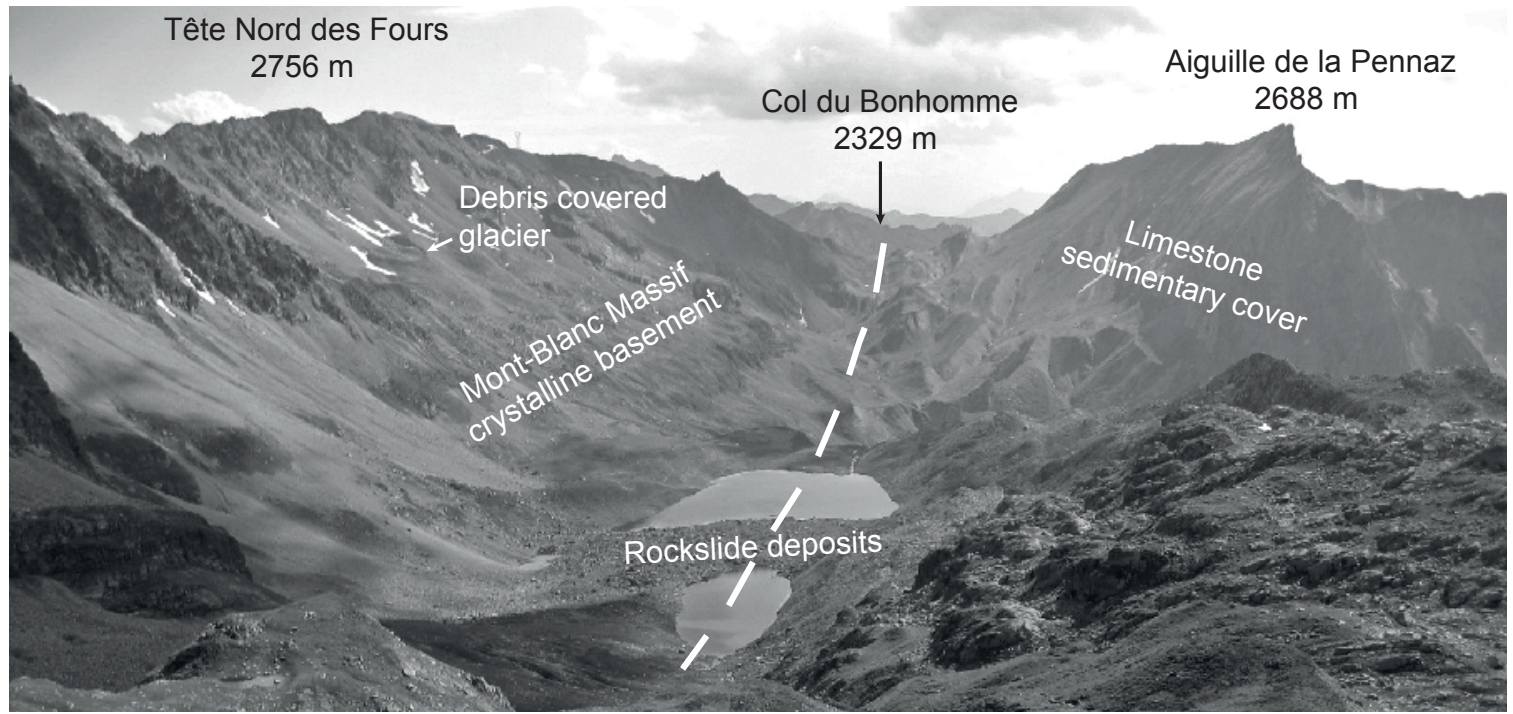

Figure 3 - Jovet lakes and Bonhomme pass. On the left, the southern margin of the Mont-Blanc massif; on the right, the Aiguille de la Pennaz, $(2688 \mathrm{~m}$ ), formed by allochtonous limestones. Jovet lakes and Bonhomme pass are situated in the same syncline (dashed line). Jovet lakes are the result of glacial erosion and linked with massive rockfall deposits above the largest lake. (C) Bosson 2009

of each landscape were assessed according to a set of weighted criteria (Table 1). We have assigned weights in terms of the importance of each criterion for geotourist purposes. Finally, two geotourist products (educational paths and website) were proposed, taking into account several factors related to the tourist promotion of sites, as, for example, the main potentially interested sections of the public (second the three categories - monomaniac, bulimic, occasional - proposed by J.-P. Pralong 2006a).

\section{Results}

CMNR geomorphological heritage richness

As for all heritages, good management of geoheritage (conservation, tourist promotion) may be based on the knowledge of its scientific value (as exhaustive as possible). To recognize the scientific intrinsic value of the CMNR geoheritage, three complementary geomorphological analyses were carried out.

The first one was geomorphological mapping applied to the whole reserve (Figure 4). The map was the basis for other geomorphological analyses and allowed us to reveal the rareness or the representativeness of local heritage. Results show a complex and diversified geomorphological heritage explained by geological contrasts, recent climate history (especially from Würmian glaciation to current Holocene interglacial) and the variation of topography (aspect, slope). Active or inherited glacial landforms dominate CMNR geomorphology. Indeed, local mesoforms (larger than $100 \mathrm{~m}$ ) are strongly linked to glacial erosion (U-shaped valley of La Rollaz and La Gorge, cirques, horns, rock basin overdeepening, etc.), even in areas where glaciers

Table 1 - Assessment grid for the scientific and geotourist values of geomorphological landscapes of the CMNR (From Pralong 2005, De Wever et al. 2006 and Reynard et al. 2007; modified).

\begin{tabular}{|c|c|c|c|}
\hline \multicolumn{4}{|l|}{ Scientific interest (intrinsic) } \\
\hline Criteria & Score (quarter of point from 0 to 1 ) & Coefficient & Value \\
\hline Integrity & From bad to good condition & 2 & \\
\hline Paleogeographical value & From no interest to remarkable & 1 & \\
\hline Rareness & From common to rare & 1 & \\
\hline Representativeness & From rare to exemplary & 1 & \\
\hline \multicolumn{4}{|c|}{ Scientific value } \\
\hline \multicolumn{4}{|l|}{ Geotourist interest } \\
\hline Criteria & Score (quarter of point from 0 to 1 ) & Coefficient & Value \\
\hline Scientific value & From no interest to remarkable & 2 & \\
\hline Educational value & From no interest to remarkable & 2 & \\
\hline Aesthetic value & From no interest to remarkable & 1 & \\
\hline Additional values & From no interest to remarkable & 1 & \\
\hline Accessibility & From no/hard access to easy access & 1 & \\
\hline Risk linked with the tourist practice & From existence to absence of risk & 1 & \\
\hline Existing tourist infrastructure & From no infrastructure to existent infrastructure & 1 & \\
\hline Sensitivity of the tourist site & From fragile to no sensitivity & 1 & \\
\hline Popularity of the tourist site & From unknown to national renown & 1 & \\
\hline & & Geotourist value & \\
\hline
\end{tabular}


disappeared more than ten thousand years ago. Quaternary glacier erosion has exploited tectonic weaknesses (faults, synclines, etc.) and, according to the domination of crystalline bedrock (gneiss), glaciershaped landforms are remarkably well conserved. In addition to relict heritage, some glacial morphogenetical systems are still active in CMNR. Obviously, they can be found in the large glacier systems of Tréla-Tête and Armancette, dominated by some MontBlanc massif summits almost $4000 \mathrm{~m}$ high (Aiguille des Glaciers, Aiguille de Tré-la-Tête, Dômes de Miage, etc.). Above the Jovet lakes, we can also observe some glaciers buried under a debris mantle (Figure 3). These black glaciers are fragments of the Little Ice Age (LIA: between 1300 and 1850/60 AD, see Ivy-Ochs et al. 2009) glacier extension. Periglacial, gravitative and fluvial landforms also occur frequently in the CMNR relief. These four morphogenetic domains (glacial, periglacial, gravitative, fluvial) are typical of high-alpine mountain morphogenesis. One of the local particularities is the frequent occurrence of landforms that result from permafrost creep related to the altitudinal decrease at the southern margin of Mont-Blanc massif. Other processes and landforms are secondary and limited to small areas in CMNR.

Recognizing numerous morainic crests and other glacial landforms (fluvio-glacial deposits, terraces, etc.) on the previous map allowed us to recreate several glacier positions (Figure 5). These different glacial stages characterize the history from the Last Glacial Maximum (LGM, around 20000 BP) up to now. Since the formation of most of the other landforms (see Figure 4) is younger than the glacier presence, a relative landscape history can be revealed with this method. For example, scree slopes in La Rollaz valley are younger than the La Villette stage. To calibrate this relative chronology, we calculated the glacier Equilibrium Line Altitude (ELA) for each stage and the depression of this limit with LIA ELA (= reference), based on the position of glacier relicts (moraines, terraces). The depression of ELA was compared and correlated with other Alpine areas. La Gorge stage may be correlated with the Younger Dryas, the last cold Late Glacial stage (between 12500 and $11500 \mathrm{BP}$ ). In response to global warming, current glaciers are mostly decreasing (surface, volume) since the LIA and some small glaciers have completely disappeared. Tré-la-Tête glacier tongue is located $2 \mathrm{~km}$ uphill from where it was during the LIA and CMNR glacier surfaces have decreased by about 35\%. In conclusion, this method allowed us to identify the paleogeographical value of local heritage.

Finally, the geosystemic analysis produced a schematic map focusing on the current geomorphological dynamics, based on the model of the sedimentary cascade (Figure 6). Results reflect the current complexity of local morphogenesis. Uphill-downhill sediment transfers imply a succession of processes (with heterogeneous dynamics). Contrasts between active areas (for example rockfalls and debris flows in Arman- cette catchment) and inactive areas (morainic covered slopes above Les Contamines-Montjoie) are clearly visible. This method also allowed us to make assumptions about the evolution of geosystems. The context of global change induces complex and ambivalent environmental responses. At low altitude (foot of slopes and valley bottom), geomorphological dynamics will probably decrease as vegetation cover expands. The situation in high mountains is more problematic and geosystems are deeply destabilized. Potential hazards linked with the degradation of permafrost, massive ice melt-out and extreme climatic phenomena (drought, storms, etc.) will increase.

According to these three analyses, CMNR geomorphological heritage is characterized by (1) great richness and diversity, (2) paleogeographical significance, (3) good general integrity and (4) the importance of active processes (especially at high elevations). Moreover, if some landforms are really locally rare (morainic crest of La Balme, debris-covered systems of Jovet valley, etc.), its main interest results in the typical and complete occurrence of Alpine morphogenetical processes. With this exemplary representativeness of Alpine landforms and processes, CMNR has an excellent educational and geotourist potential that could be developed around three themes: glacial heritage (rich and omnipresent), landscape history (glacial and postglacial geomorphology) and current high mountain destabilization.

\section{Geotourist promotion of CMNR geomorpho- logical heritage}

In a second step, the scientific and geotourist values of local geomorphological landscapes were assessed (Table 2). Results show a high scientific value of landscapes overall (from 0.55 to 0.95 ; mean $=0.79$ ) and a quite high geotourist value (from 0.46 to 0.79 ; mean $=0.65)$. Five particular geomorphological landscapes (Tré-la-Tête valley, Le Plan de la Fenêtre - Pastures of la Balme - Les Près, La Rollaz valley, Plan Jovet and Jovet lakes valley) are highlighted by a high scientific and geotourist value. All calculated values are the expression of specific situations. The conservation state of the landscapes, the absence of forest (good visibility of heritage) and current dynamics (good educational value) were significant positive factors for the geotourist values. In contrast, inaccessibility, the presence of forests and natural hazards were negative factors. Public access of CMNR is by foot only. The distance (up to $10 \mathrm{~km}$ ) and the difference in height (up to $1300 \mathrm{~m}$ ) between most of the landscapes and the two main parking lots (La Gorge and Le Cugnon) can be a significant problem for the development of geotourism. Thus, mountain hiking ability can be a discriminating criterion for geotourists in CMNR. Moreover, these characteristics imply visits of long duration (several hours to entire days). Weather and climate conditions can also create some difficulties and geotourism should be practiced between spring and autumn with 


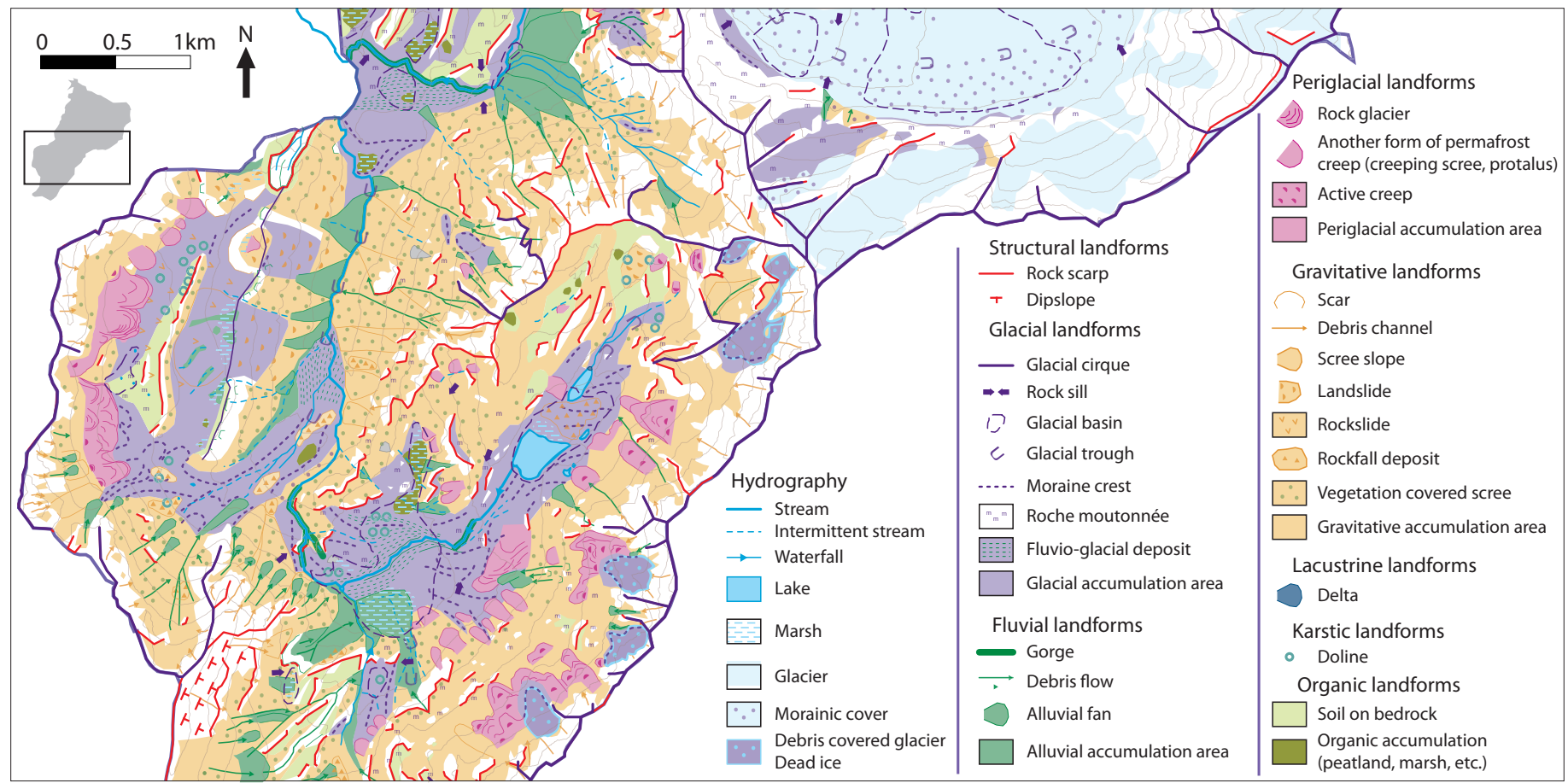

Figure 4 - Extract of the geomorphological map of CMNR, created with the University of Lausanne legend (Bosson 2010; modified).

good weather conditions (landforms have to be visible). In addition to these evaluations, the potential target public for each landscape was discussed in terms of site complexity, educational value and accessibility.

From these results, two projects of local geomorphological heritage tourist promotion were proposed. They are not definitive and only exist as a planning stage to date. The first proposal is a set of classical geotourist educational paths (Figure 7). Four itineraries were conceived, based on the three more pertinent local geotourist themes. These paths cover the geomorphological landscapes with the highest geotourist value. Explanatory folders should be created for each path, adapted to target public. Dynamic and aesthetic values of such heritage should be promoted through these field experiences.

Contrasting with these sportive proposals, an embryonic interactive website was created (Figure 8). The main page is composed by a Google Earth application, where scientific interpretations on CMNR geoheritage can be added. The tool is really interactive and users can choose the information they want to visualize (check boxes). Explanatory pages with additional maps and figures complete interactive interpretations. They can be consulted online or downloaded. With this modern and virtual approach of geovisualization, the idea is to give another kind of public access to geoheritage (for people that cannot visit CMNR or for dangerous and fragile natural areas) and scientific knowledge. Moreover, Google Earth with its 3D graphics and its easy navigation (scale variation, modification of the viewing angle) is an extraordinary tool for geoheritage (and especially geomorphological heritage) visualization and promotion.

\section{Discussion and conclusion}

We agree with Brun (2008, p. 89) when he says that "Alpine research now aims to promote an integrated vision of Alpine territories focusing on creating and maintaining spatial and temporal networks of sustainable relationships between humans and the other components of the ecosphere [the whole of nature]. It combines resource usage with conservation of the biological [geological (!)] and cultural diversity that makes up the Alpine identity."

The scientific study of the geomorphological heritage, the evaluation of the geotourist values and the proposals for the geoheritage promotion show that a development of geotourism based on geomorphological heritage is relevant in CMNR. Along with the promotion of intrinsic local richness, the effects of current global warming in mountain environments (massive glacier melt-out, morphogenetic crisis, etc.) can be introduced to the public. Thus, especially with a field experience, the public can have a better understanding of the complexity of global change and its impacts on mountain environments. It can lead to a better awareness of current issues and to the necessity of preserving an extremely rich, diversified and fragile natural environment (see the concept of dynamic protection in Coratza 2004).

We have tried to present the results of this study and the proposals for educational and tourist activities related to geoheritage to the managers of the reserve. After nearly two years and without knowing the reasons (time, means, interest, willingness?), the objective of this approach, i.e. to share scientific knowledge with institutions and/or the wider public, unfortunately remains unachieved. Thus, we may wonder if geotourism and geoconservation approaches are more 


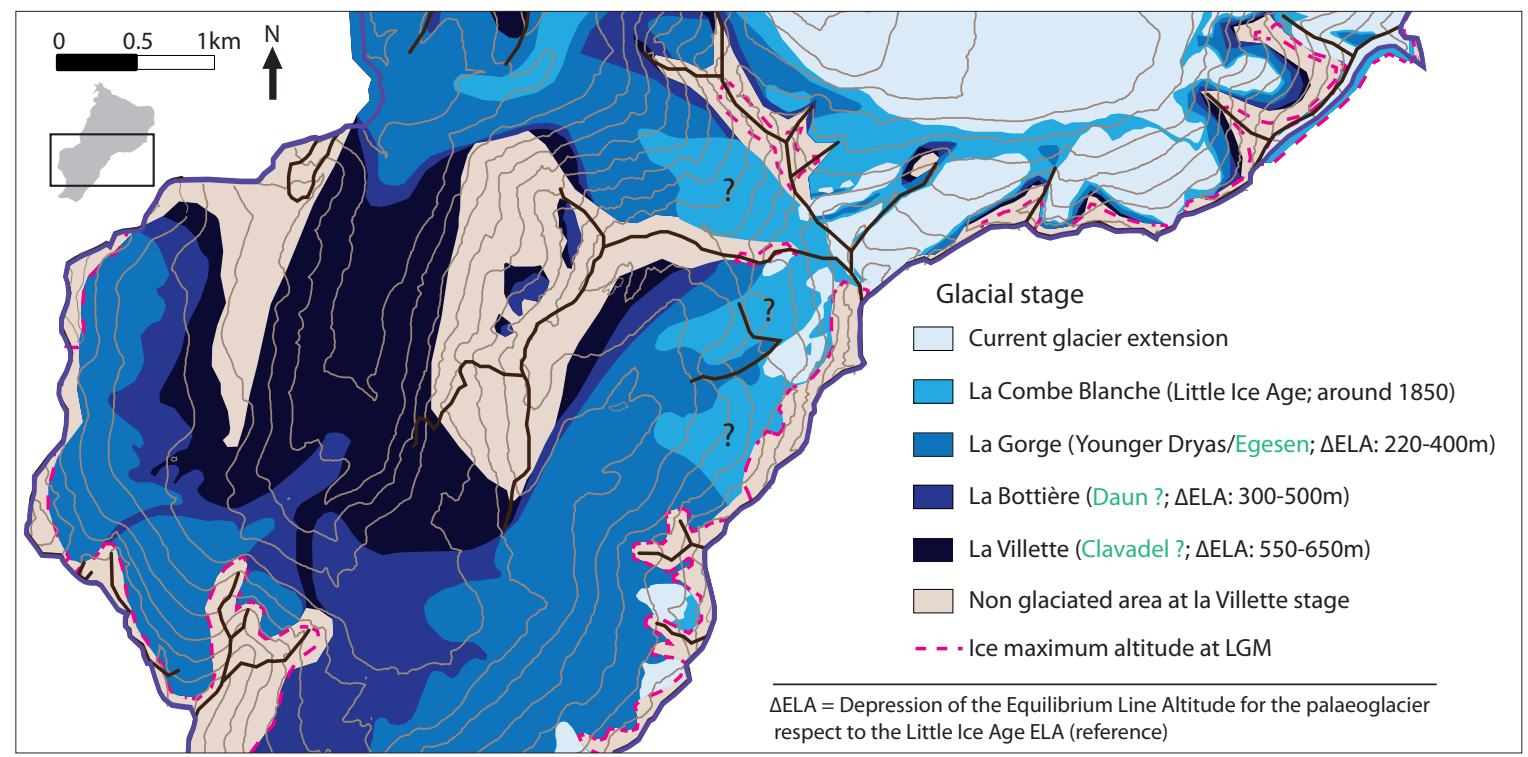

Figure 5 - Reconstitution of the paleoglacier surfaces of CMNR. More extended glacial stage (Saint-Gervais-les-Bains, Magland) and Last Glacial Maximum are not represented in this map. Correlations with the Eastern Alps glacier retreat model (Maisch 1981) are proposed in green in the legend (Bosson 2010; modified).

a geoscientists' dream rather than a response to a real social demand. In this way, as suggested by Martin et al. (2010), the development of each geotourist product should be based on a complete evaluation of the public (more broadly of all tourist actors), site, contents and support characteristics. In a second step, specific choices (objectives, targets, means, etc.) have to be made to realize relevant tourist products. This clear, complete and systematic approach has not been followed enough in our work in CMNR. In this case, the reason is probably due to the difficulty of dialogue between scientists and park managers.

Nevertheless, although geodiversity seems less fragile than biodiversity, numerous significant impacts can be pointed out (Serrano \& Ruiz-Flaño 2009). Moreover, the case of CMNR shows that even rich geodiversity attracts insufficient consideration on the part of the natural area management. Thus, geoscientists, who know more about the intrinsic richness of geoheritage (and its real or potential threats), should continue to in-

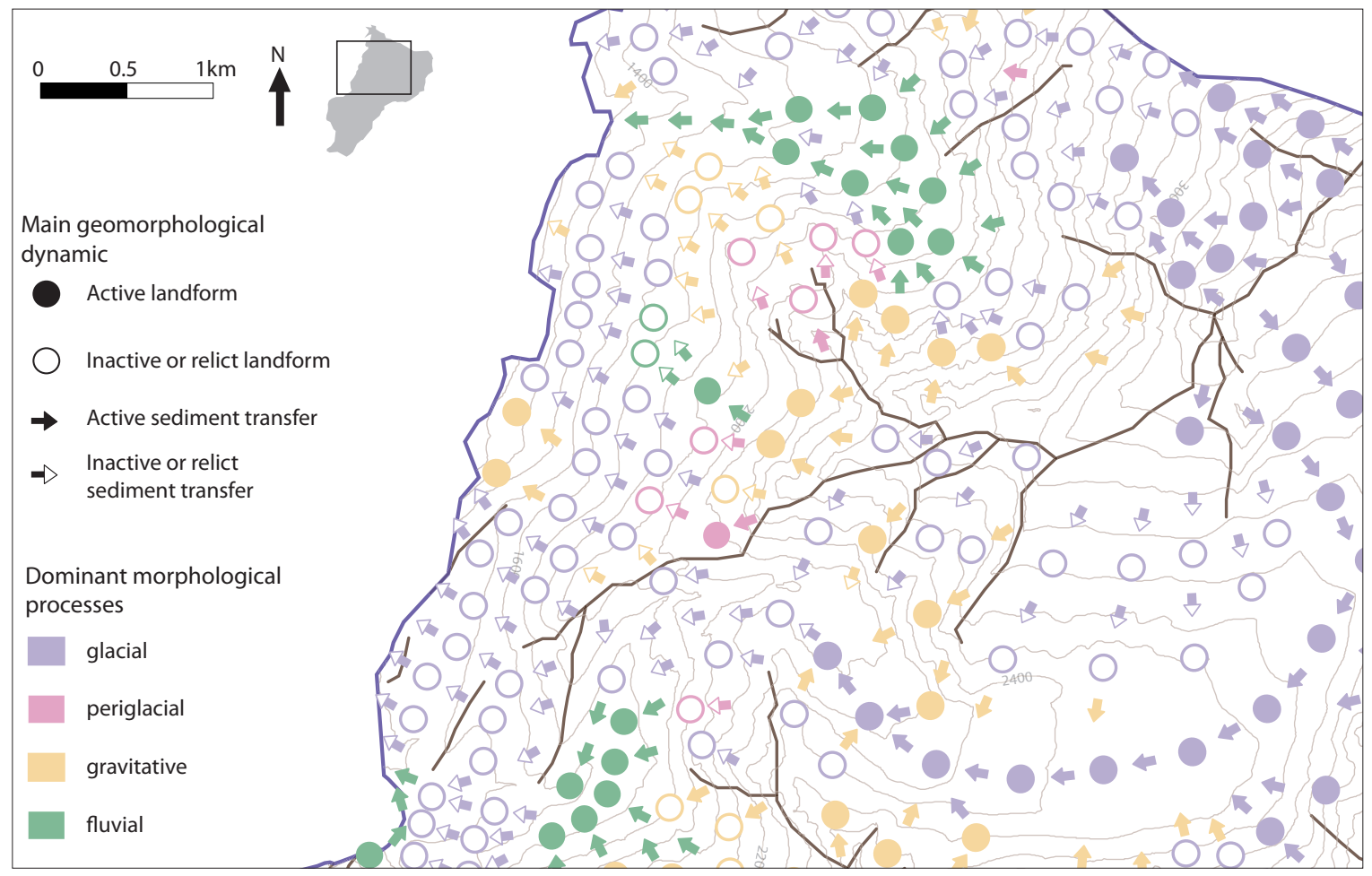

Figure 6 - Extract of the geosystemic map of CMNR showing parts of Tré-la-Tête valley and Armancette catchments. In the upper part, we can see, for example, the active debris flow system of Armancette that downstream mobilizes especially LIA relict moraines (Bosson 2010; modified). 
Table 2 - Synthesis of scientific and geotourist value after evaluation for details, see Bosson 2010.

\begin{tabular}{|c|c|c|c|c|c|c|}
\hline $\begin{array}{l}\text { Geomorphological } \\
\text { landscape (GL) }\end{array}$ & $\begin{array}{l}\text { Area } \\
\text { (ha) }\end{array}$ & $\begin{array}{l}\text { Scientific } \\
\text { value } \\
\text { (on 1) }\end{array}$ & $\begin{array}{l}\text { Geotourist } \\
\text { value } \\
\text { (on 1) }\end{array}$ & $\begin{array}{l}\text { Site complexity } \\
\text { (morphogenesis, } \\
\text { dynamics) }\end{array}$ & $\begin{array}{l}\text { Potential } \\
\text { target public } \\
\text { (see Pralong, } \\
\text { 2006a) }\end{array}$ & \\
\hline $\begin{array}{l}\text { Armancette catch- } \\
\text { ment }\end{array}$ & 760 & 0.8 & 0.46 & medium & $\begin{array}{l}\text { occasional, } \\
\text { bulimic }\end{array}$ & $\begin{array}{ll}+ & \text { global scientific value } \\
- & \text { presence of forest; } \text { natural hazard occurrence } \\
= & \text { limited relevance for geotourist purposes }\end{array}$ \\
\hline Tré-la-Tête valley & 1750 & 0.85 & 0.76 & low & $\begin{array}{l}\text { bulimic, mono- } \\
\text { maniac }\end{array}$ & $\begin{array}{l}+\quad \text { global scientific and geotourist value; high current dynamic due to global } \\
\text { warming } \\
\text { - } \quad \text { limited accessibility (high mountain); natural hazard occurrence } \\
=\text { good potential for geotourist purposes but limited target public }\end{array}$ \\
\hline $\begin{array}{l}\text { Tête Noire - La } \\
\text { Combe Blanche }\end{array}$ & 390 & 0.55 & 0.55 & medium & $\begin{array}{l}\text { bulimic, mono- } \\
\text { maniac }\end{array}$ & $\begin{array}{ll}+ & \text { integrity and representativeness of landforms } \\
- & \text { presence of forest and of infrastructure } \\
= & \text { medium potential for geotourist purposes }\end{array}$ \\
\hline La Rosière & 105 & 0.8 & 0.62 & low & bulimic & $\begin{array}{ll}+ & \text { global scientific value (high ecological value) } \\
- & \text { presence of forest and sensitivity of the site } \\
= & \text { good potential for geotourist purposes, especially in a wider herit- } \\
\text { age promotion }\end{array}$ \\
\hline $\begin{array}{l}\text { Le Plan de la Fenêtre } \\
\text { - Pastures of La } \\
\text { Balme - Les Près }\end{array}$ & 260 & 0.8 & 0.69 & high & $\begin{array}{l}\text { bulimic, mono- } \\
\text { maniac }\end{array}$ & $\begin{array}{l}+ \text { global scientific and geotourist value (diversity, absence of forest) } \\
=\text { good potential for geotourist purposes }\end{array}$ \\
\hline $\begin{array}{l}\text { La Rollaz valley (La } \\
\text { Giettaz - La Balme) }\end{array}$ & 495 & 0.85 & 0.79 & medium & $\begin{array}{l}\text { occasional, } \\
\text { bulimic }\end{array}$ & $\begin{array}{l}+ \text { global scientific and geotourist value (aesthetical and educational value) } \\
=\text { good potential for geotourist purposes }\end{array}$ \\
\hline Plan Jovet & 440 & 0.8 & 0.71 & high & $\begin{array}{l}\text { occasional, } \\
\text { bulimic, mono- } \\
\text { maniac }\end{array}$ & $\begin{array}{l}+ \text { global scientific and geotourist value (aesthetical and ecological value) } \\
-\quad \text { long access, absence of tourist infrastructure, sensitivity of the site } \\
=\text { good potential for geotourist purposes, especially in a wider herit- } \\
\text { age promotion }\end{array}$ \\
\hline Jovet lakes valley & 340 & 0.95 & 0.72 & high & $\begin{array}{l}\text { occasional, } \\
\text { bulimic, mono- } \\
\text { maniac }\end{array}$ & $\begin{array}{ll}+ & \text { global scientific and geotourist value (aesthetical, educational and eco- } \\
- & \text { logical value) } \\
= & \text { long access, absence of tourist infrastructure, sensitivity } \\
& \text { good potential for geotourist purposes }\end{array}$ \\
\hline $\begin{array}{l}\text { Les Rebanets Chas- } \\
\text { sot }\end{array}$ & 175 & 0.9 & 0.57 & high & monomaniac & $\begin{array}{l}+ \text { global scientific value } \\
-\quad \text { limited accessibility (high mountain); natural hazard occurrence } \\
=\quad \text { rather a research site than a geotourist site }\end{array}$ \\
\hline $\begin{array}{l}\text { Bonhomme pass } \\
\text { (Plan des Dames - } \\
\text { La Saussaz) }\end{array}$ & 400 & 0.65 & 0.62 & medium & bulimic & $\begin{array}{l}+\quad \text { global scientific and geotourist value (educational, aesthetical) } \\
-\quad \text { long access, absence of tourist infrastructure, sensitivity } \\
=\quad \text { good potential for geotourist purposes, especially in a wider herit- } \\
\text { age promotion }\end{array}$ \\
\hline
\end{tabular}

form institutions, local inhabitants and the wider public. Consequently, geoconservation and geotourism are mostly related to bottom-up, proactive and committed dynamics originating from the scientific sphere. Numerous examples of projects or realizations illustrate this implication of the geoscientist community (see e.g. Cayla 2009 or Reynard et al. 2009). In 2011, the integration of Les Bauges Natural Regional Park (French Alps) into the European Geopark Networks (see e.g. Zouros 2009), initiated jointly by scientists and park managers, is an emblematic example of a successful approach (Hobléa et al. 2011). The intrinsic value of geoheritage is being progressively recognized (Reynard et al. 2011), sometimes directly in relation to natural protected area (NPA) perimeters. Following Tardiff's studies (2003), NPAs seem to be privileged areas for such strategies, bringing together rich and protected natural heritage and their institutional tools for sustainable management and promotion.

On a local scale, surveys of the public's needs have demonstrated that it is important to promote not only the geological heritage but also the natural environment and the cultural values that make up the specificities of the territory, with the aim of reconstructing the so-called total history (Pralong 2006b) of the landscape and territory. This approach can help the wider public to understand the links between the environmental sphere and society and should give visitors the keys to understanding how important it is to change behaviour and to protect the natural environments in order to preserve the delicate balance of nature. The geomorphological landscape (Reynard 2005) is a good gateway to build this kind of integrated education of environmental challenges. Indeed, the visibility of landforms in the landscape, their aesthetic, the dynamics of processes that allow the observation of the environmental changes in action at a human scale (compared to many other geological processes) and their quite strong relationships with other types of heritage (biological, cultural) make the geomorphological heritage an ideal field for environmental education. The closely linked richness of CMNR heritage values - geoheritage (structures, landforms, glaciers), bioheritage (wetlands, lakes, biodiversity, rare species), and cultural heritage (Roman roads, pastures, mountaineering, water resource management) - is a perfect vehicle for such kind of integrated promotion and education about local heritage, and the CMNR could be a good laboratory to test and develop the proposed approach.

\section{References}

Asters 2004. Plan de gestion 2006-2010 de la Réserve Naturelle des Contamines-Montjoie. Pringy. 


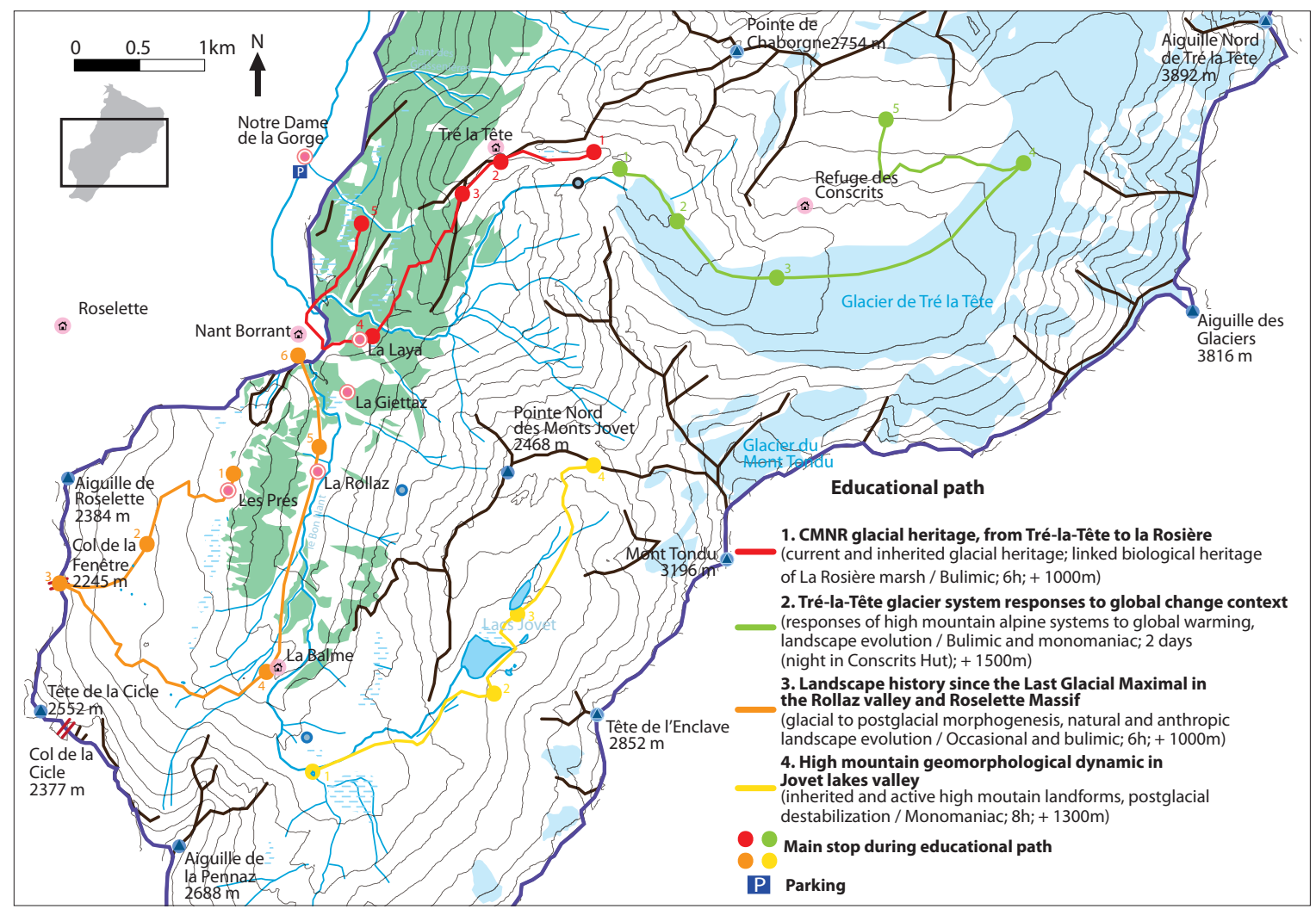

Figure 7 - Map representing the four proposed educational paths (from Bosson 2010, modified), with indication of the targeted publics (after Pralong (2006a) classification) and tourist information (walking time, drop).

Ballandras,S.2003. Réalitéetlogiques desgéosystèmes montagnards alpins - Principes de fonctionnement morphodynamique. Cahiers de Géographie 1: 123-133.

Bosson, J.-B. 2010. Contribution à l'étude du patrimoine géomorphologique de la Réserve Naturelle des Contamines Montjoie et démarche de géovalorisation. Mémoire de master, Université de Lausanne. Available at: http://mesoscaphe.unil.ch/igul/memoires/bd/ (accessed: 21/11/12)

Bourdeau, P. 2009. From après-ski to après-tourism: the Alps in transition? Revue de géographie alpine 97 (3). Available at: http://rga.revues.org/1049

Brun, J.-J. 2008. Alpine research today. Revue de géographie alpine 96 (4): 89-100.

Carcavilla, L., J.J. Durán, Á. García-Cortés \& J. López-Martínez 2009. Geological heritage and geoconservation in Spain: past, present, and future. Geoberitage 1: 75-91.

Cayla, N. 2009. Le patrimoine géologique de l'arc alpin. De la médiation scientifique à la valorisation géotouristique. Thèse de doctorat, Université de Savoie. Available at: http://tel.archives-ouvertes.fr (accessed: 21/11/12)

Coratza, P. 2004. Géomorphologie et culture: exemples de valorisation en Emilie Romagne (Italie). In: Reynard, E. \& J.-P. Pralong (eds.), Paysages géomorphologiques. Université de Lausanne, Institut de Géoprahie. Travaux et recherches 27: 209-223.

De Wever, P., Y. Le Nechet \& A. Cornée 2006. Vademecum pour l'inventaire du patrimoine géologique national. Mémoire Hors Série de la Société Géologique de France 12. Available at: http://inpn.mnhn.fr/isb/ download/fr/docPatGeol.jsp (accessed: 21/11/12)

Dowling, R. \& D. Newsome (eds.) 2006. Geotourism. Amsterdam.

Fontana, G. \& E. Reynard 2012. La gestion du patrimoine géologique dans les parcs naturels en Suisse. In: Giusti, C. (ed.), Géomorphosites: imagerie, inventaire, mise en valeur et vulgarisation du patrimoine géomorphologique: 129-135. Paris.

Gray, M. 2004. Geodiversity. Valuing and conserving the abiotic nature. Chichester.

Hobléa, F., N. Cayla, A. Guyomard, C. Peisser \& P. Renau 2011. Géosciences et projets de territoire: comparaison et conciliation de trois projets de géoparcs dans les Préalpes françaises du Nord. In: Reynard E., L. Laigre \& N. Kramar (eds.), Les géosciences au service de la société. Actes du colloque en l'honneur du Professeur Michel Marthaler, Université de Lausanne. Géovisions 37: 21-36.

Hose, T.A. 1996. Geotourism, or can tourists become casual rock hounds? In: Bennett, M.R., P. Doyle, J.G. Larwood \& C.D. Prosser (eds.), Geology on your Doorstep. The role of urban geology in earth heritage conservation: 207-228. London

Hose, T. A. 2008. Towards a history of geotourism: definitions, antecedents and the future. In: Burek, C. V. \& C.D. Prosser (eds.). The history of geoconservation: 37-60. London.

Ivy-Ochs, S., H. Kerschner, M. Maisch, M. Christl, P. Kubik \& C. Schlüchter 2009. Latest Pleistocene and 


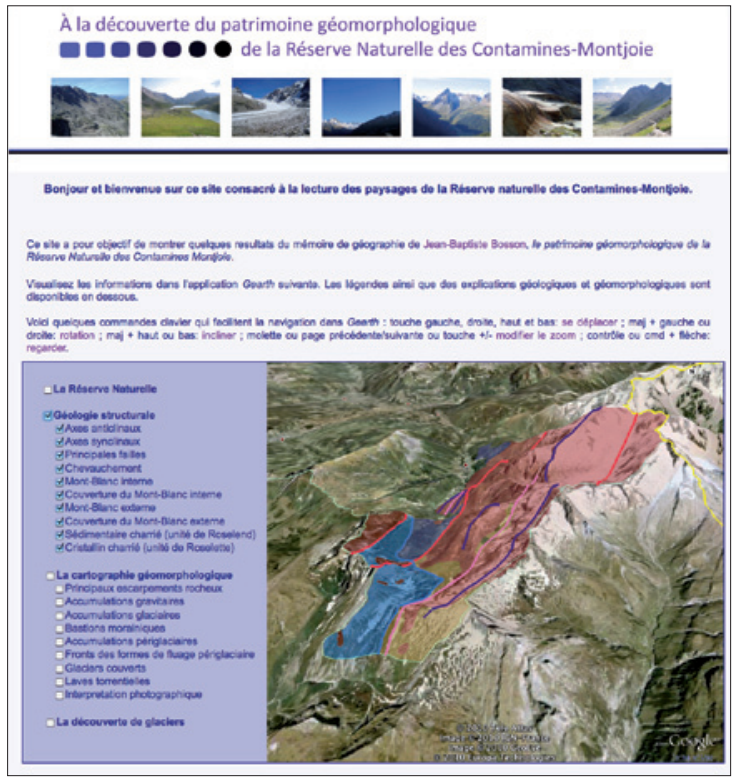

Figure 8 - Extract of the website project's main page: http:/ / mesoscaphe.unil.ch/geovis_igul/gm_contamines/

Holocene glacier variations in the European Alps. Quaternary Science Reviews 28: 2137-2149.

Kozlik, L. in prep. Geoheritage importance in Regional Nature Parks in the Jura Range. In: Hobléa, F. et al. (ed.), Proceedings of the International Symposium on Geosite Management.

Macchiavelli, A. 2009. Alpine tourism. Revue de géographie alpine 97 (1). Available at: http:/ / rga.revues.org/818

Maisch, M. 1981. Glazialmorphologische und Gletschergeschichtliche Untersuchungen im Gebiet zwischen Landwasserund Albulatal (Kt. Graubünden, Schweiq). Dissertation, Universität Zurich, Physische Geographie.

Martin, S., G. Regolini-Bissig, A. Perret \& L. Kozlik 2010. Elaboration et évaluation de produits géotoursitiques. Propositions méthodologiques. Téoros 29 (2): 55-66.

Panizza, M. 2001. Geomorphosites: concepts, methods and example of geomorphological survey. Chinese Science Bulletin 46 Suppl. Bd: 4-6.

Pralong, J.-P. 2005. A method for assessing tourist potential and use of geomorphological sites. Géomorphologie: relief, processus, environnement 3: 189-196.

Pralong, J.-P. 2006a. Géotourisme et utilisation de sites naturels d'intérêt pour les sciences de la Terre: les regions de Crans-Montana-Sierre (Valais, Alpes suisses) et Chamonix-Mont-Blanc (Haute-Savoie, Alpes françaises). Thèse, Université de Lausanne. Travaux et Recherches 32

Pralong, J.-P. 2006b. Geotourism: a new form of tourism utilising natural landscapes and based on imagination and emotion. Tourism Revue 61 (3): 20-25.

Reynard, E. 2005. Géomorphosites et paysages. Géomorphologie: relief, processus, environnement 3: 177-180.

Reynard, E., G. Fontana, L. Kozlik \& C. Scapozza 2007. A method for assessing the scientific and additional values of geomorphosites. Geographica Helvetica 62: 148-158.
Reynard, E., P. Coratza \& G. Regolini-Bissig (eds.) 2009. Geomorphosites. München.

Reynard, E., F. Hobléa, N. Cayla \& C. Gauchon 2011. Iconic sites for alpine geology and geomorphology. Revue de géographie alpine 99 (2). Available at: http:/ / rga.revues.org/1412

Sharples, C. 2002. Concepts and principles of geoconservation. [electronic publication], published in September 2002 on the Tasmanian Parks \& Wildlife Service website.

Schoeneich, P. 1993. Comparaison des systèmes de légendes français, allemand et suisse - Principes de la légende IGUL. In: Schoeneich, P., \& E. Reynard (eds.), Cartographie géomorphologique - Cartographie des risques. Université de Lausanne, Institut de géographie, Travaux et Recherches 9: 15-24.

Schoeneich, P., E. Reynard E. \& G. Pierrehumbert 1998. Geomorphological mapping in the Swiss Alps and Prealps. In: Kriz, K. (Hrsg.), Hochgebirgskartographie Silvretta '98, Wiener Schriften zur Geographie und Kartographie 11: 145-153.

Schrott, L., G. Hufschmidt, M. Hankammer, T. Hoffmann \& R. Dikau 2003. Spatial distribution of sediment storage types and quantification of valley fill deposits in an Alpine basin, Reintal, Bavarian Alps, Germany. Geomorphology 55: 45-63.

Serrano, E. \& P. Ruiz-Flaño 2007. Geodiversity. A theoretical and applied concept. Geographica Helvetica 62: 140-147.

Serrano, E. \& P. Ruiz-Flaño 2009. Geomorphosites and geodiversity. In: Reynard, E., P. Coratza \& G. Regolini-Bissig (eds.), Geomorphosites: 49-61. München.

Tardiff, J. 2003. Ecotourisme et développement durable. VertigO 4 (1). Available at: http:/ / vertigo.revues. org $/ 4575$

Zouros, N. 2009. Geomorphosites within geoparks. In: Reynard, E., P. Coratza \& G. Regolini-Bissig (eds.), Geomorphosites: 105-118. München.

\section{Authors}

\section{Jean-Baptiste Bosson}

has a Bachelor in political sciences from the University of Lyon 3 and a Master in geography from the University of Lausanne. He is currently working on the geomorphological evolution of the Alpine cryosphere for his $\mathrm{PhD}$ at the University of Lausanne. email: jean-baptiste.bosson@unil.ch

\section{Emmanuel Reynard}

is professor of physical geography at the University of Lausanne. His main research interests are the study of Alpine landscape evolution, geoheritage assessment and management and water management in mountain areas.

email: emmanuel.reynard@unil.ch

Institut de Géographie, Université de Lausanne, Anthropole, CH-1015 Lausanne 